\title{
Biogeography of Dragonflies and Damselflies: Highly Mobile Predators
}

\author{
Melissa Sánchez-Herrera and Jessica L. Ware \\ Department of Biology, Rutgers The State University of New Jersey, Newark Campus, \\ USA
}

\section{Introduction}

Dragonflies (Anisoptera) damselflies (Zygoptera) and Anisozygoptera comprise the three suborders of Odonata ("toothed ones"), often referred to as odonates. The Odonata are invaluable models for studies in ecology, behavior, evolutionary biology and biogeography and, along with mayflies (Ephemeroptera), make up the Palaeoptera, the basal-most group of winged insects. The Palaeoptera are thought to have diverged during the Jurassic (Grimaldi and Engel, 2005; Thomas et al., 2011), and as the basal-most pterygote group, odonates provide glimpses into the entomological past. Furthermore, few other insect groups possess as strong a fossil record as the Odonata and its precursors, the Protodonata, with numerous crown and stem group fossils from deposits worldwide.

Their conspicuous behavior, striking colors and relatively small number of species (compared to other insect orders) has encouraged odonatological study. Odonates are important predators during both their larval and adult stages. They are often the top predators in freshwater ecosystems, such as rivers and lakes. One of their most remarkable traits, however, is their reproductive behavior, which takes place in a tandem position with the male and female engaging in a "copulatory wheel" (Fig. 1).

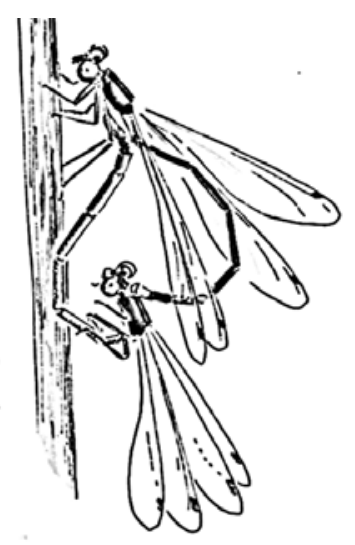

Fig. 1. Odonata copulatory wheel (modified from Eva Paulson illustration Aug, 2010). 
During the last 5 decades, our understanding about the ecology and evolution of Odonata has increased dramatically (e.g., Cordoba-Aguilar, 2008). A fair odonate fossil record coupled with recent advances in molecular techniques, have inspired several biogeographical studies of Odonata. The aim in this chapter is to review current understanding of odonate biogeography, to add new insights about the evolutionary history of this order, and to evaluate the contribution of odonatology to our overall understanding of biogeographical patterns. Furthermore, we discuss how this information may be used to develop predictions about relationships between current environmental alterations, such as climate change and deforestation, may affect the ranges and dispersal of Odonata. We also frame Odonata biogeography in the context of developing better mechanisms for the conservation of these important insects.

\section{What are dragonflies and damselflies? Real hunters}

The Odonata are one of the most ancient groups of extant insects. Fossils of the stem group order Protoodonata (stem fossil group, containing no extant representatives), recognizable progenitors of modern day dragonflies, date from middle Carboniferous Serpukhovian sediments formed almost 325 million years ago (Brauckman \& Zessin, 1989). One such protoodonate, Meganeura, had a wingspan of over $30 \mathrm{~cm}$ (Brongniart, 1885; see Fig. 2 of Typus permianus, another Meganeuridae), and extremely dense wing venation. Protoodonate wing shapes suggest that they may have been capable of fast flight and although they were likely as voracious as present day dragonflies (Corbet, 1999), they may have been less agile due to their large size.

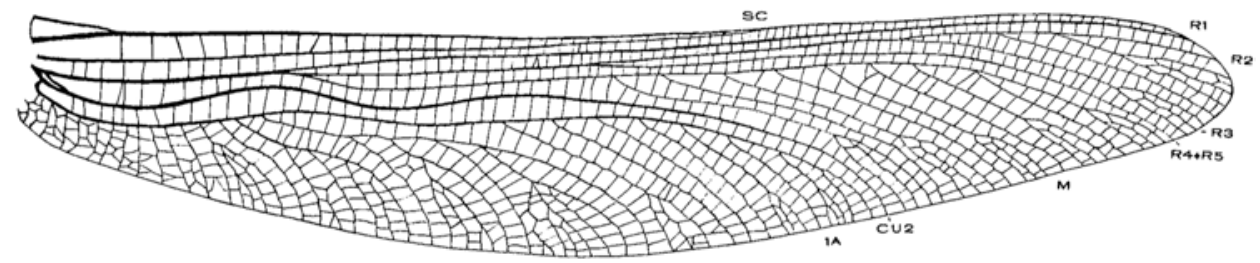

Fig. 2. The Protoodonate representative: Typus permianus forewing (modified from Carpenter 1931).

The first crown group odonate fossils (crown group fossil = extant representatives exist) date from the lower Permian period (ca. 250 million years ago); these fossils are not the huge Carboniferous monsters of Protoodonata, but rather the Protoanisoptera and early protozygopterans (Clarke, 1973; Carpenter, 1992; Wootton, 1981) were similar in size to modern dragonflies. Although all modern odonates have aquatic or semi-terrestrial juvenile stages (Watson, 1981), there is little fossil evidence to support that early odonates had aquatic larvae (Pritchard, 1993; Wootton, 1981). Larvae fossils are unknown before the Mesozoic, but by the Middle Triassic there is evidence the characteristic prehensile labium, ubiquitous in modern-day larvae, and of differences among larval habits in some zygopterans (coenagrionids) and anisozygoptererans. The former suggest that larvae possibly became aquatic during the Lower Permian (Corbet, 1999).

Odonata are relatively generalized insects; as members of the "Hemimetabola" they do not have a pupal stage between the larvae and the adult stage. Their larvae are confined to fresh 
or brackish waters and they develop rudimentary wing covers when they are about half grown. They show an incredible diversity of forms depending on the characteristics of the aquatic niche occupied, whether lentic or lotic.

\subsection{Ecology and behavior}

Dragonflies are voracious predators in larval and adult life stages, feeding exclusively on living prey. Larvae detect prey visually and with mechanoreceptors (Fig. 3), primarily as sitand-wait predators. This is a successful strategy, in part due to a particularly distinctive odonate larval characteristic: prehensile mouthparts (labium) that can be extended to capture prey (Fig. 4 A). Several larger odonate taxa are considered top predators in the food chain of their freshwater ecosystems. As adults, odonates usually eat small flying insects, which they are able to detect using their globe-like eyes. Their spiny legs are used as a basket to net prey and move it forward during flight to their strong mandibles (Fig. $4 \mathrm{~A}$ ). Most Odonata species feed during flight, which is not an easy task despite their being exceptional flyers (Corbet, 1999).

A.

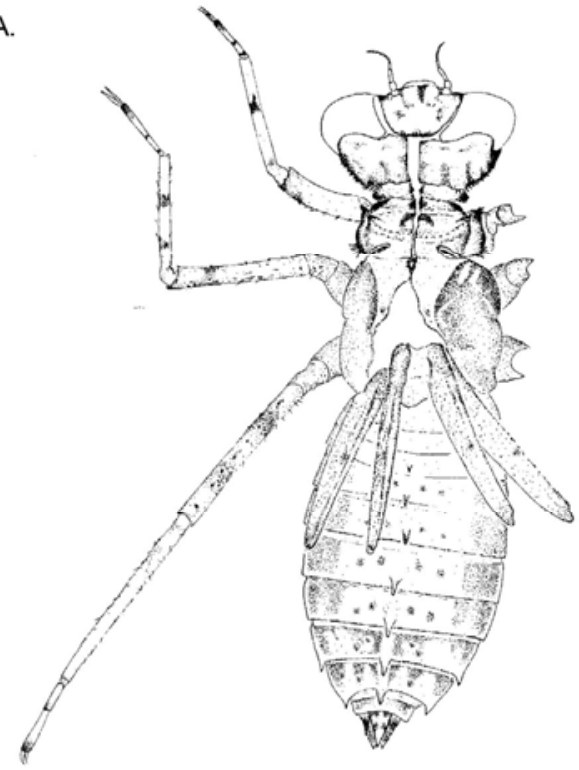

B.

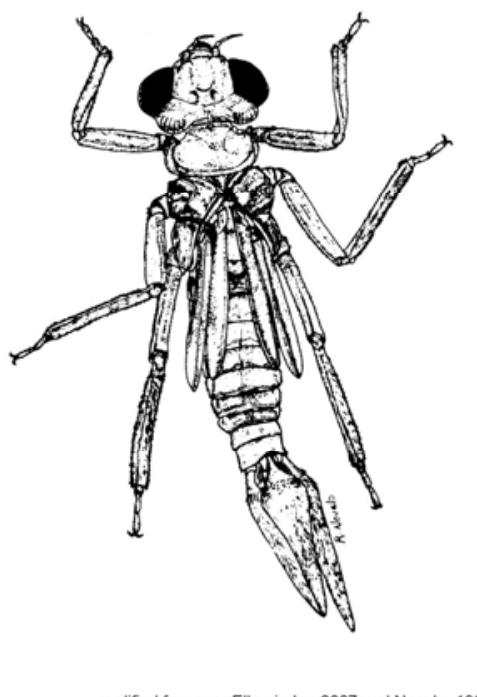

Fig. 3. Odonata larvae. A. Dragonfly Macrothemis hageni. B. Damselfly Amphypteryx longicaudata.

Dragonflies and damselflies have long slender abdomens, short antennae, huge spherical eyes, (so large that they can sometimes make up the bulk of the head). Larval Zygoptera have caudal gills and swim by paddling with their legs, whereas larval Anisoptera have largely internal gills and move by jetting water from their abdomens. Adult Odonata have long wings with a conspicuous nodus and a pterostigma (Fig. 4 B). The latter is weighted and helps stabilize the wing during flight (Norberg, 1972). The wing apparently bends and flexes rather widely around the nodus during flight. 

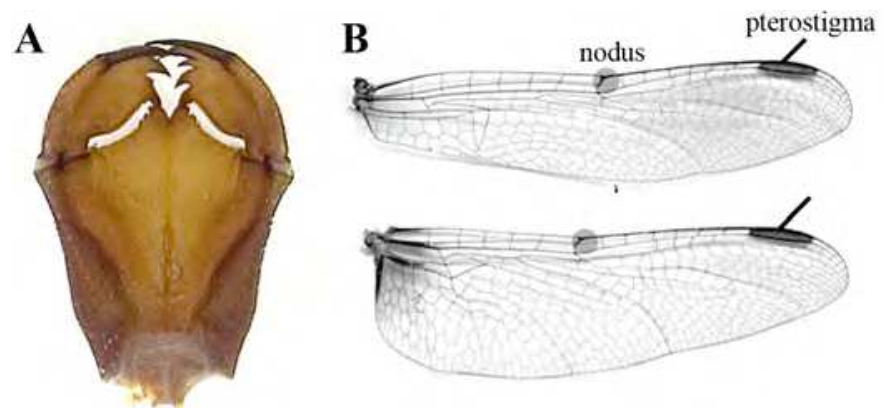

Fig. 4. A. Neopetalia punctata prenhesile labium. B. Pachydiplax longipennis wings showing the conspicuous nodus and pterostigma. Images: Jessica Ware

Unique among all Ptergyota is the odonate method of copulation, which involves indirect fertilization. Male dragonflies and damselflies have secondary genitalia at the base of their abdomens. Sperm is produced in the testes and released from the abdomen tip and then placed in the secondary copulatory organs on the underside of the second segment of the abdomen prior to copulation. During copulation, the female receives sperm from the male's vesica spermalis, a secondary penile structure at the base of the male abdomen, into her bursa copulatrix, or sperm storage organ. Females can mate multiple times, storing sperm in their body for later use. In turn, the male secondary organ can remove or displace the sperm of previous matings using the penes to increase their chances for paternity. Sperm competition in odonates has made them a well-studied taxonomic group in the field of sexual selection and reproductive behavior.

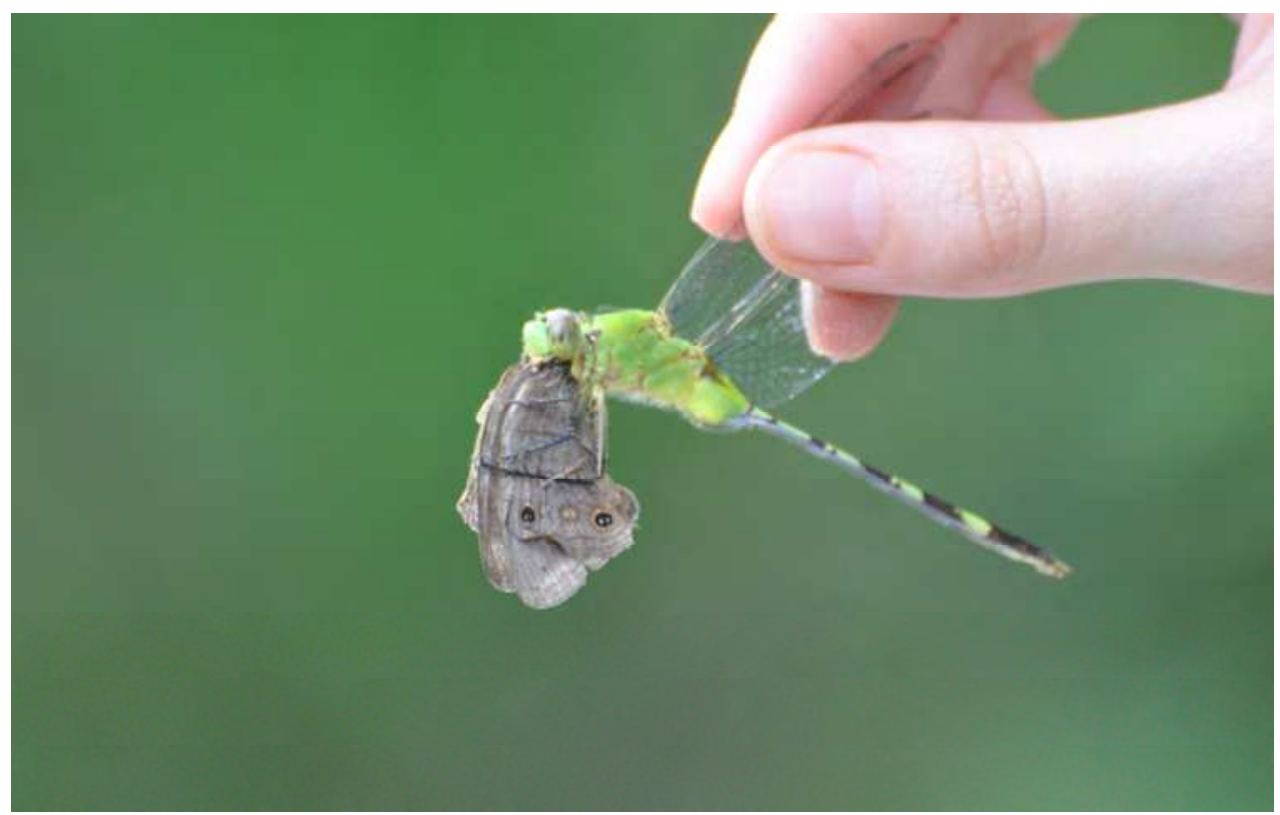

Fig. 5. Erythemis vesiculosa eating a Satyrinae butterfly. Image: Dr. Godfrey Bourne. 


\subsection{Species diversity and biogeography}

Recently, a monogeneric third suborder was recognized with two extant species from Japan and the eastern Himalayas (Epiophlebia, Selys 1889; ). Anisozygopterans have some features recalling Zygoptera, such as petiolate wings, and some of Anisoptera, such as robust abdomens. Recent phylogenetic studies have reconstructed this suborder within the Anisoptera, and thus (Anisoptera + Anisozygoptera) have been called Epiprocta (e.g. Bechly, 1996, Lohmann, 1996; Bybee et al., 2008). Currently taxonomy suggests that there are eleven families in Anisoptera: Aeshnidae, Austropetaliidae, Gomphidae, Petaluridae, Cordulegastridae, Neopetaliidae, Chlorogomphidae, GSI (sensu Ware et al., 2007), Corduliidae, Macromiidae and Libellulidae, with Epiophlebiidae from Anisozygoptera considered by some to be an twelfth family of dragonflies. Although both Zygoptera and Anisoptera have roughly 3000 species, Zygoptera are divided into 21 families: Amphipterygidae, Calopterygidae, Chlorocyphidae, Coenagrionidae, Dicteriadidae, Euphaeidae, Hemiphlebiidae, Isostictidae, Lestidae, Lestoidedidae, Megapodagrionidae, Perilestidae, Philogangidae, Platycnemidae, Platystictidae, Polythoridae, Protoneuridae, Pseudolestidae, Pseudostigmatidae, Synlestidae, and Thaumatoneuridae.

Present-day distribution of Odonata reflects millions of years of geographic isolation and dispersal, coupled with adaptation over 300 million years of climate variation (Fig. 6). This has contributed to considerable speciation and endemism (Samways, 1992, 2006), particularly in the tropics, although speciation has been elevated among several Holarctic

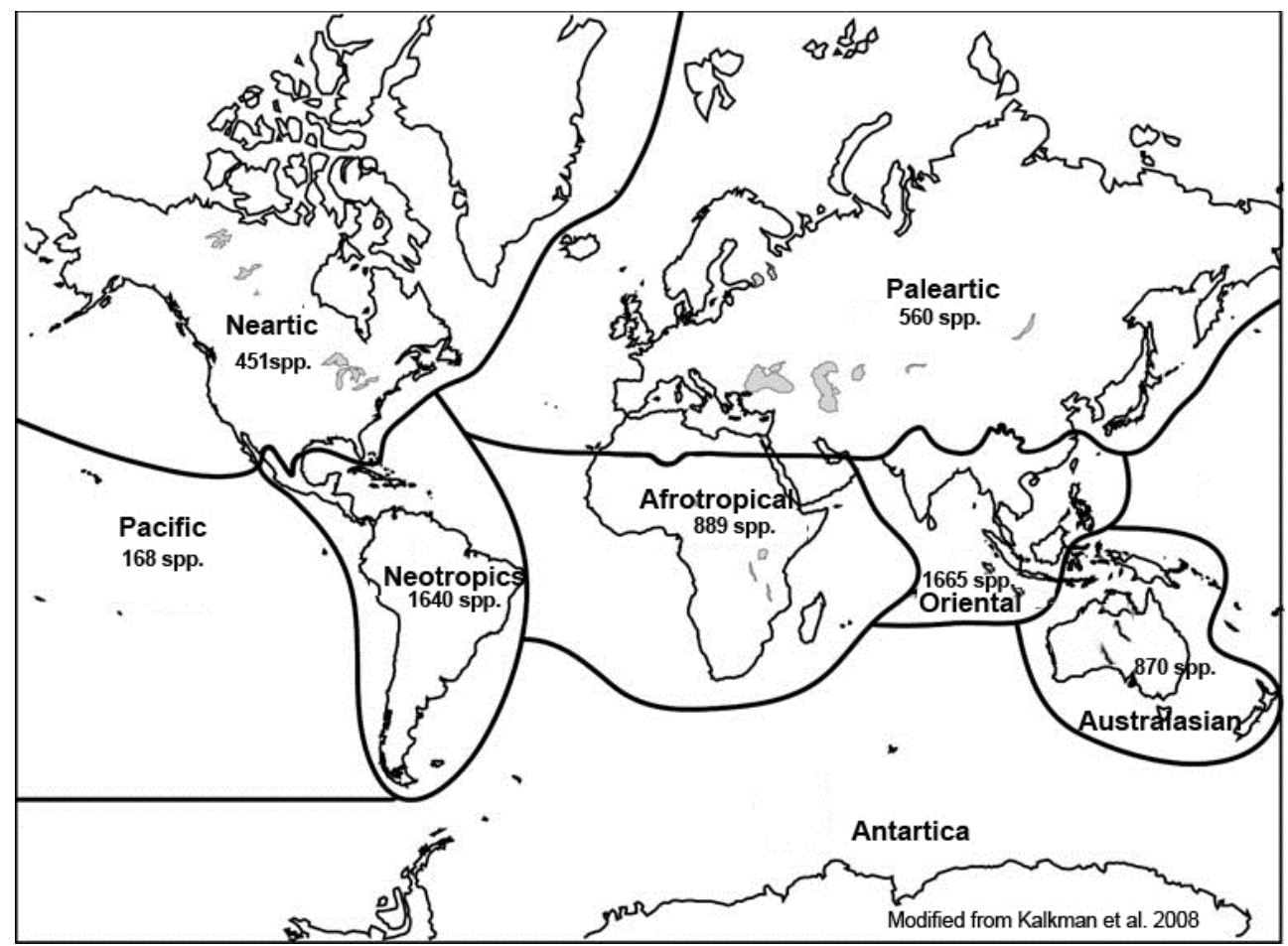

Fig. 6. Current odonate species diversity distribution. 
taxa (e.g., Brown et al., 2000). In a warming global climate, current odonate biogeography will undoubtedly change. The habitat requirements of high elevation taxa may leave some montane specialists without suitable habitat (Samways, 1992, Stevens and Bailowitz, 2009), while tropical, warm-adapted taxa may expand their ranges to higher latitudes. Increasing isolation of populations in moist tropical environments due to deforestation, increasing temperatures, and flow regulation, with arid and unsuitable habitat in between (Samways, 2006), may lead to species loss.

\subsection{Dispersal in Odonata, flight behavior and migration}

Many Odonata are highly mobile and have varying levels of dispersal capabilities (e.g. Kormandy, 1961). Anax, the common green darner, Pantala, the wandering glider, and several other odonates, in fact, are capable of migrating very long distances. The north-south migration of Anax junius occurs for the most part in North America (e.g., Russell et al., 1998), with migrants moving up to $2800 \mathrm{~km}$ south (Wilkelski et al., 2006; May, 2008). Gene flow occurs among migrant and resident 'subpopulations' resulting in a panmictic population (Freeland et al., 2003; Matthews et al., 2007). Pantala, a highly migratory dragonfly, is even more cosmopolitan, with individuals found on all continents except Antarctica, although they not equally common on all continents (McLachlan, 1896; Wakana, 1959; Reichholf, 1973; Rowe, 1987; Russell et al., 1998; Corbet ,1999 ; Srygley, 2003; Feng et al., 2006; Buden, 2010). Pantala uses passive dispersal for example, to cross the Indian Ocean (e.g. Anderson et al., 2010;), while maintaining local island populations, such as those on Easter Island (Samways and Osbourne, 1998). The other 25-50 putative migratory Odonata (Kormondy, 1961) include Sympetrum corruptum, Erythrodiplax umbrata, several species of Tramea, and Libellula quadrimaculata (Artiss, 2004). Most odonates are thought to migrate by taking advantage of wind currents, and most migratory taxa are in the superfamily Libelluloidea.

Anisoptera are typically much stronger fliers than are damselflies. Heiser and Schmitt (2010) suggested that the relative dispersal capabilities of dragonflies and damselflies differentially influenced biogeographical patterns among Palaearctic taxa. An analysis of biogeographical patterns for that region showed that Anisoptera biogeographical patterns reflected historical vicariance and dispersal events, while relatively poorly dispersing Zygoptera showed distributions that seemed to reflect more the effect of climate (Heiser and Schmitt, 2010). However, dispersal capability alone does not determine observed biogeographical patterns. For example, Hemicordulia, appears to be capable of dispersing but may be a poor competitor (Dijkstra, 2007a, b), and its distribution may be more a reflection of simple vicariance.

\section{Anisoptera phylogeny}

Anisoptera are unequivocally monophyletic (e.g., Rehn 2004; Carle et al., 2008; Bybee et al., 2008). Frustratingly, interfamilal relationships among taxa have remained in conflict due to disagreements in recent phylogenetic hypotheses. In particular disagreement, yet of great interest, is the placement of Gomphidae, which has been recovered as sister to the Libelluloidea (e.g., Bybee et al., 2008, one analysis) and as sister to the Petaluroidea (e.g., Letsch, 2007). Gomphidae and Libelluloidea share exophytic oviposition behavior (i.e., eggs laid outside of plant tissue) and both have reduced or vestigal ovipositors, their egg laying aparati. Whether this is a synapomorphy or due to convergence is of phylogenetic interest. 
Molecular phylogeographical analyses in Anisoptera are few, but several non-molecular studies directly or tangentially discuss anisopteran biogeography (e.g., Carle, 1995; Leiftinck, 1977). Further complicating matters is the fact that there are relatively few studies that have incorporated fossil and extant taxa in such analyses (with exceptions, see Bybee et al., 2008). With as geographically vast and geologically ancient a group as dragonflies, biogeographical analyses failing to incorporate fossils may not reveal much of their true history and the potential past impacts of ancient vicariant events.

\subsection{Biogeography of the dragonfly superfamily Libelluloidea and Australian endemism}

Ware et al. (2008) used molecular data to analyze the biogeography of an anisopteran taxon, the libelluloid Syncordulia. Their analysis suggested that the biogeography of the endemic South African taxon Syncordulia was a result of a southwestern Cape origin, approximately 60 million years ago. Syncordulia is a member of the family Synthemistidae s.s. (called "GSI" by Ware et al., 2007; previously considered to be members of the Corduliidae s.l.). The other taxa in this family are mostly Australasian endemics. The region studied has a high level of dragonfly endemism. Within the GSI, only Gomphomacromia (South American), Idionyx and Macromidia (IndoMalayan), and Oxygastra (Europe) are found outside of Australia and New Zealand, although other New World taxa, such as Lauromacromia, or Neocordulia, and African taxa such as Neophya, whose phylogenetic position have yet to be determined may ultimately be determined to be members of the Synthemistidae. The fossil record, however, suggests a more widespread distribution for several present-day Australasian endemics. The Mesozoic fossil taxon Cretaneophya, for example, thought to be sister to the extant West African Neophya, has been found in fossil deposits in Southeastern England (Jarzembowski $\&$ Nel, 1996). Similarly, the Argentinian fossil Palaeophya argentina is a putative member of the Cordulephyidae, a taxonomic group whose extant representatives are restricted to Australia (Petrulevicius \& Nel, 2009).

Libelluloidea has been estimated to diverge during the Jurassic (e.g., Thomas et al., 2011) or Early Cretaceous (Jarzembowski \& Nel, 1996; Fleck et al., 2008). Although at that time the continents were still in close proximity, the break-up of the supercontinent of Pangaea created the southwest Indian Ocean rift, splitting South America + Africa from East Gondwanaland and moving India away from Antarctica, and the North Atlantic- Caribbean rift, which separated Laurasia from South America and Africa (Dietz \& Holden, 1970). If ancestral Libelluloidea (Fig. 7 A, B)were present on all landmasses, the subsequent isolation resulted in geographical vicariance that may have influenced divergence. Our unpublished estimate for the divergence of non-cordulegastrid taxa was 132 Mya, based on molecular data and estimated using a BEAST Bayesian analysis. This age estimate is similar to that of Carle (1995), who suggested that the radiation of non-cordulegastrid Libelluloidea began 'at least 140 million years ago'. During the early Cretaceous, Gondwanaland began to break apart more fully (e.g., Veevers, 2004), creating geographical barriers to dispersal and the isolation of populations. Vicariant events such as those have been suggested to drive the rate of speciation (e.g., Nelson, 1969; Rosen, 1975, 1978; Platnick \& Nelson, 1978; Nelson \& Rosen, 1980; Nelson \& Platnick, 1981; Wiley, 1981). Tectonics may have resulted in increased uplift and increased inland water habitat (e.g., Hallam, 1993), and the occurrence of additional water sources may have encouraged Odonata dispersal. 
By far the most extensive biogeographical study of Afrotropical libelluloid taxa was undertaken by Dijkstra (2007), who evaluated current distributions of odonates in tropical Africa and retrodicted past biogeographical patterns. African taxa are far less species rich than their Neotropical or Asian congeners; for example, African Aeshnidae, for example include 39 species among 5 genera, while there are 127 species among 15 genera in the Neotropics, and 138 species among 18 genera in the Orient (Dijkstra, 2007). Although species richness is low in several African regions, there are high levels of endemism (e.g., Clausnitzer \& Dijkstra, 2005; Dijkstra, 2007).

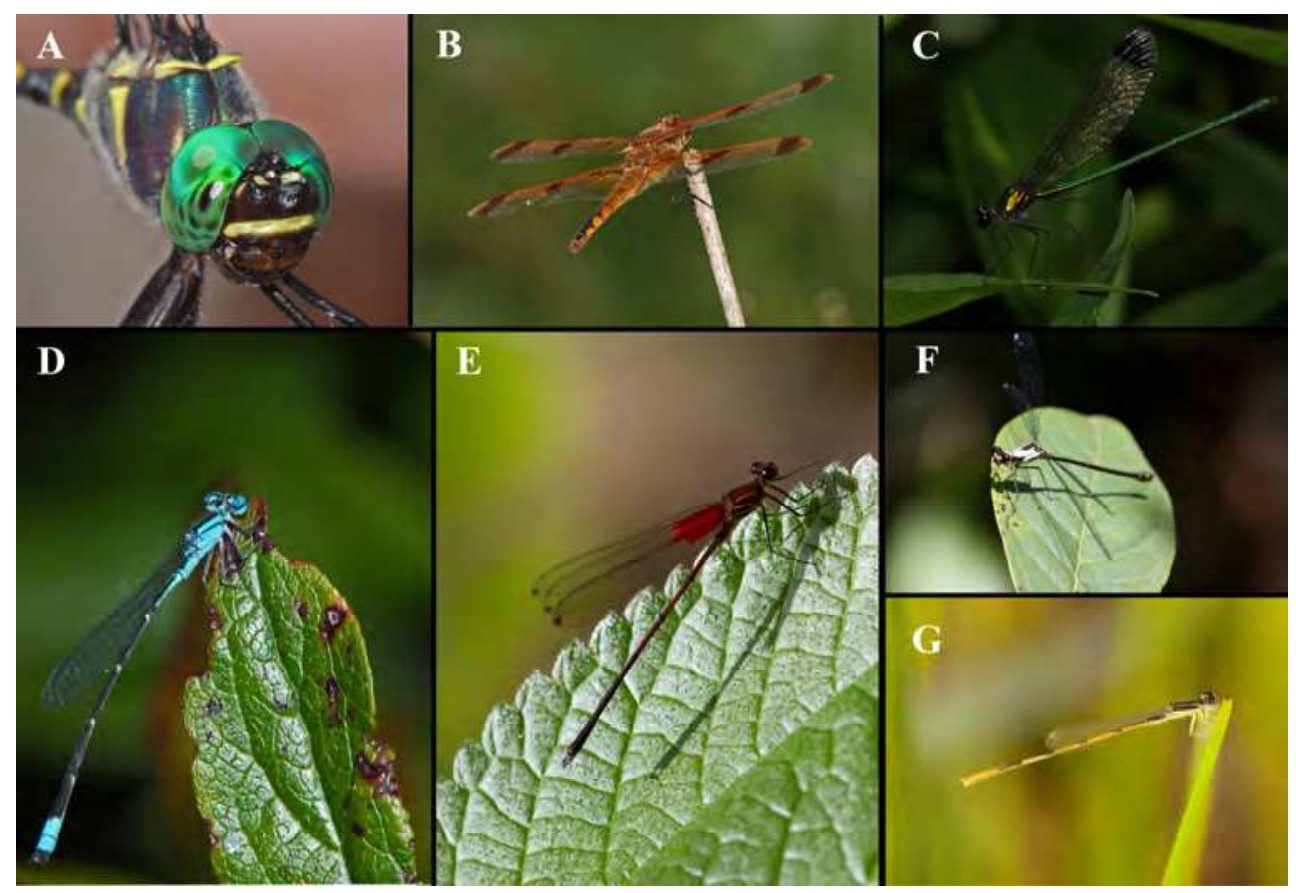

Fig. 7. Several Odonate taxa involved in the biogeographical studies. A. Georgia River Crusier (Macromia georgina) B. Painted Skimmer (Libellula semifaciata) C. Sparkling Jewelwing (Calopteryx dimidiata) D. Slender Bluelet (Enallagma traviatum) E. Rubyspot (Hetaerina occisa) F. Megapodagrionidae (Teinopodagrion macropus) and G. Citrine Forktail (Ischnura hastata). Images A,B,C,D copyright from Dan Irizarry and Images E, F and G copyright from Adolfo Cordero.

\section{Biogeography of Zygoptera}

These slender and often rather small odonates are still taxonomically unresolved. Rehn (2003) proposed phylogenetic hypotheses that supported zygopteran monophyly based on morphological characters: nine morphological synapomorphies support Zygoptera. However several molecular Odonata phylogenetic analyses have failed to recover damselflies as a monophyletic group (Hasegawa \& Kasuya, 2006, Saux et al., 2003). Recently, Bybee and colleagues (2008) used both molecular and morphological data and supported the monophyletic status of this taxon, suggesting that molecular data alone fails 
to recover a monophyletic Zygoptera due in part to limited taxon sampling. Nevertheless, internal familial relationships within the suborder remaining tangled, with families such as Megapodagrionidae, Perilestidae, Amphypteridae, Coenagrionidae, and Protoneuridae examples of putatively paraphyletic groups that will likely need to be reclassified (Bybee et al. 2008).

A limited number of studies have explored the effects of key biogeographical events on individual damselfly taxa (De Marmels, 2001; Dumont et al., 2005; Groeneveld et al., 2007; Polhemus, 1997; Turgeon et al., 2005). Today, patterns of damselfly distributions coincide with climatological zones: as temperature increases near the equator so too does the diversity of Zygoptera increase (Kalkman et al, 2008). Tropical regions hold the greatest number of species, and it has been suggested that this high diversity can be explained by aquatic habitat abundance in tropical forest (Orr, 2006). Moreover, tropical mountains provide a diversity of niches and regional refugia (Kalkman et al., 2008). The limited seasonality of tropical habitats increases the opportunities for specialist life-styles, thereby supporting the high diversity of tropical odonates and other taxa.

Within the damselflies the most successful family is indisputably the Coenagrionidae, in part due likely to their capacity for colonization. This family has been recovered as paraphyletic in recent systematic work (Bybee et al., 2008; O'Grady \& May, 2003). Within this family, several genera (Enallagma, Ischnura, Melagrion) show a broad range of biogeographical patterns (Polhemus, 1997; Brown et al., 2000; Turgeon et al., 2002). Enallagma damselflies (Fig. 7 D) are present on all continents except Australia and Antarctica (Bridges, 1997). Their distribution shows two centers of diversification: North America and sub-Saharan Africa, with scattered species around the Asian and Palaearctic regions (Brown et al., 2000). This genus is one of the most species rich in North America, with 38 described species (Westfall \& May, 1996). Recent molecular phylogenetic reconstructions of the Nearctic members of this genus suggest a radiation that relied on two recent progenitor lineages, the "E. hageni" and "E. carunculatum" clades (Brown et al., 2000). Turgeon et al. (2005) explored the diversification history of Enallagma across the Holarctic region using previous molecular phylogenetic work (Brown et al., 2000; Turgeon et al., 2002) and AFLP's as population genetic markers among species. There they suggested that the recent radiation of Enallagma was due to strong climate variation during Quaternary epoch.

The fork-tail damselflies (Ischnura, Fig.7 G) are the smallest members of the Coenagrionidae but have colonized most continents. Some species show female color polymorphism (e.g., I. e.g., ramburii; Cordero, 1990b, 1992; Fincke, 1987, 2004; Hinnekint, 1987; Johnson, 1964, 1966, 1975; Robertson, 1985; Robinson \& Allgeyer, 1996; Sirot et al., 2003) and sperm competition (Cooper et al., 1996; Cordero, 1990a; Cordero \& Miller, 1992; Miller, 1987; Waage, 1984). Recently, Ischnura hastata, a widespread species, was found to exhibit parthenogenesis in populations only in the Azores islands (Cordero et al., 2005), making this genus a good model for more extensive biogeographical analyses. Chippindale et al. (1999) explored phylogenetic relationships among North American Ischnura species, reporting a recent diversification along a latitudinal gradient. Realpe (2010) described two new species present in high altitudes of the Andes Cordillera in South America, and unpublished molecular data of those species suggest evidence of a recent radiation across elevation in the Neotropics (Realpe \& Sanchez-Herrera, pers. comm.). The great dispersal ability of some fork-tail damselflies may have contributed to multiple rapid radiation events through their evolutionary history. 
Megalagrion is one of the most species rich genera in the Pacific Region (Donelly, 1990). This genus contains 23 described species found on all the main Hawaiian Islands (Polhemus \& Asquith, 1996; Daigle, 1996; Polhemus, 1997). Endemicity and species richness appear related to island age (Jordan et al., 2003). Molecular data on these species reveals two basic diversification patterns across the islands (Jordan et al., 2003). Some species dispersed in tandem as new islands were created, and over time those founding populations have lead to endemic species and assemblages on each island. Still other taxa show an adaptive burst as a single representative of a lineage colonized new islands (Jordan et al., 2003).

The family Megapodagrionidae (Fig. 7 F) appears to be paraphyletic (Bybee et al., 2008). De Marmels (2001) morphologically revised the Neotropical genus complex Megapodagrion s.str. (Megapodagrion, Allopodagrion and Teionopodaprion) which are distributed throughout South America. He suggested that high speciation rates in South American tropical forests were due to orogenic development of the southeastern Brazilian mountains and the Andes in Oligocene/Miocene times. Furthermore, he reported high degree of specialization within genera for particular Neotropical forests. Finally, he suggested a closer morphological relationship of this complex to taxa in the Malayan and Austral-Papuan region, based on the penile morphology (De Marmels, 2001).

The family Pseudostigmatidae is strikingly large but is restricted to Central and South America lowland montane forests (Fincke, 1992). The largest extant odonate is the helicopter damselfly Megaloprepus coerulatus with a wingspan approximately of $19 \mathrm{~cm}$ and an abdomen length of $10 \mathrm{~cm}$. Recently, Groeneveld et al. (2007) addressed the evolution of gigantism among members of this family and an Eastern Africa endemic species, Coryphagrion grandis. The latter species had been placed in the family Megapodagrionidae; however, their habitat preferences, morphology, and behavior suggest they either lie in a monogeneric family or fall in the Pseudostigmatidae (Clausnitzer \& Lindeboom, 2002; Rehn, 2003). Using molecular data from representative species of Pseudostigmatidae and Coryphagrion, Groeneveld et al. (2007?) suggest that gigantism evolved only once through the evolutionary history of this taxa. Their results support that gigantism in the endemic African genus was a reflection of phylogenetic history, and that this genus was a Gondwanaland relict (Groeneveld et al., 2007).

The family Calopterygidae is a monophyletic family within the Zygoptera (Bybee et al., 2008, Dumont et al., 2005). It is distributed worldwide, except for the Australasian region. All of the members of this family share remarkably similar habitat requirements (running waters) and morphology; however, males show a variety of mating displays (Buchholtz, 1995; Heymer, 1972). Dumont et al. (2005) evaluated phylogenetic relationships among species, but due to sparse Neotropical taxon sampling intrafamilial relationships remain unclear. Nevertheless, recent molecular phylogenetics among the Calopterygidae have clarified some biogeographical patterns (Dumont et al., 2005; Mullen \& Andres, 2007). Fossil evidence and molecular dating techniques indicated that this family arose approximately $175 \mathrm{Ma}$ and underwent rapid diversification approximately $150 \mathrm{Ma}$ during the Cretaceous period (Dumont et al., 2005). Several Gondwanaland disjunctions exist among these taxa, such as the relictual distributions of Irydictyon and Noguchiphaea. Dumont et al. (2005) also reported that temperate taxa, such as Calcopteryx (Fig. 7 C), were affected by Pleistocene glaciation. Recently, Mullen and Andres (2007) used molecular systematic and phylogenetic methods on Calcopteryx and suggesting that this taxon has been present since the Miocene 
age; furthermore, they suggest that reproductive displays may be a result of reinforcement or ecological character displacement dating from when isolated populations came into secondary contact. Phylogenetic relationships remain unclear in the Neotropical genus Hetaerina (Fig. 7 E), despite the fact that unlike other confamilial genera male genitalia are strongly divergent, suggesting mechanical isolation (Garrison, 1990).

Forest damselflies in the family Platystictidae are restricted to Central and northern South America, and to tropical Southeast Asia. Morphological and molecular data indicate they are a monophyletic taxon (Bechly, 1996; Rehn, 2003; van Tol et al., 2009). These forest dwellers have poor flying capacity, suggesting low dispersal capability, which is reflected in the small distributional ranges of most species (van Tol et al., 2009). Molecular analysis recovered Neotropical genera as the basal-most clades within the family. However, the morphological analyses suggest that Sinosticta ogati from southeastern China is instead the sister taxon to all other members of the family. Consequently, the ancestor of the family may have evolved in the Palaearctic and the Oriental regions (van Tol et al., 2009). This type of distribution has been recognized among other organisms, such as the Neotropical plant genus Trigonobalanus (van der Hammen \& Cleef, 1983), and it is known as a "tropical amphitranspacific distribution" (van Steenis, 1962). This pattern is ascribed to dispersal from Africa to the northern hemisphere during the Late Cretaceous, with subsequent extinction in Africa due to Neogene desertification (Raven \& Axelrod, 1974). van Tol et al. (2009) hypothesized an origin in eastern Africa, suggesting that the ancestor of this family evolved in eastern Gondwana, with subsequent dispersal into South America, Asia, and New Guinea. Although the family includes Neotropical taxa, additional Neotropical sampling is needed to test this hypothesis.

Finally, the distribution of members of the Afrotropical family Platycnemidae has been suggested to be the result of insular island biogeography. Dijkstra et al. (2007) described Platycnemis pembipes, a new species from the Pemba Island of Tanzania. He examined the morphology of all members of this genus, concluding that the new species was more related to Malagasy taxa than to Guineo-Congolian species, which have affinity to tropical Asia. The distribution of this new species suggests a remarkable colonization event probably due to wind dispersal across the Mozambique channel (Dijkstra et al., 2007).

Overall, many biogeographical mechanisms that have been proposed using damselflies as model organisms, but more thorough sampling and a greater variety of ecological experimentation is needed to further advance understanding of damselfly evolution and biogeography.

\section{Conclusion}

The biogeography of Odonata is a rich area of study that needs further attention. As one of the basal-most taxa in Insecta (Grimaldi and Engel, 2005), our understanding of the origin of flying insects will be greatly improved by additional study, particularly through research that includes thorough analyses of stem and crown group taxa. Future work should explore the biogeography of lesser-studied zygopteran groups from South America, and expand understanding of species rich groups like the Libelluloidea and Gomphidae. Dragonflies and damselflies have been heralded as model indicators for climate change, due in part to their great dispersal capabilities, and earlier emergence has been documented in our 
warming climate (e.g., Hassell et al., 2007). Range expansion of tropical taxa is predicted into higher latitudes. Although some Odonata ranges fluctuate with environmental changes, northward range expansions have been reported over the last 40 years among several European taxa (e.g., Hickling et al., 2005). The future biogeographical distribution of Odonata undoubtedly will be influenced directly and indirectly by anthropogenicallyaltered climate.

\section{Acknowledgments}

J.W. and M. S. H. acknowledge internal funding from Rutgers University in Newark. Moreover we thank Dr. Godfrey Bourne, Dan Irizarry, Dr. Adolfo Cordero and Eva Paulson for sharing the amazing pictures we used in our figures. Finally, we acknowledge Dr. Larry Stevens for the review edits that enrich our chapter.

\section{References}

Anderson, R.C. (2009). Do dragonflies migrate across the western Indian Ocean? Journal of Tropical Ecology, 25, 347-348.

Artiss, T. (2004). Phylogeography of a facultatively migratory dragonfly, Libellula quadrimaculata (Odonata: Anisoptera). Hydrobiologia 515, 225-234.

Bechly, G. (1996). Morphologische Untersuchungen am Flügelgeäder der rezenten Libellen und deren Stammgruppenvertreter (Insecta; Pterygota; Odonata). unter besonderer Berücksichtigung der Phylogenetischen Systematik und des Grundplanes der Odonata. Petalura, special vol. 2, 402 pp.

Brauckmen, C. \& Zessin, W. (1989). Neue Meganeuridae aus dem Namurium von HagenVorhalle (BRD). und die Phylogenie der Meganisoptera (Insecta, Odonata). Deutsche entomologische Zeitschrift 36, 177-215, pl 3-8.

Brongniart, C. (1885). Les insectes fossiles des terrains primaires. Coup d'oeil rapide sur la faune entomologique des terrains paléozoïques. Bulletin of the Societe Amis Sci. nat. Rouen, 1885, 50-68.

Brown, J. M., M. A. McPeek \& May, M. L. (2000). A phylogenetic perspective on habitat shifts and diversity in the North American Enallagma damselflies. Systematic Biology, 49, 697-712.

Buden, D. W. (2010). Pantala flavescens (Insecta: Odonata) rides west winds into sal. Pacific Science, 64, 141-143.

Bybee, S.M., Ogden, H.T., Branham, M.A. \& Whiting, M.F. (2008). Molecules, morphology and fossils: a comprehensive approach to odonate phylogeny and the evolution of the odonate wing, Cladistics, 23, 1-38.

Carle, F.L. (1995). Evolution, taxonomy, and biogeography of ancient Gondwanian libelluloides, with comments on anisopteroid evolution and phylogenetic systematics (Anisoptera: Libelluloidea). Odonatologica, 24, 383-506.

Carpenter, F.M. (1992). Volume 3: Superclass Insecta. In R.C. Moore, R.L. Kaesler, E. Brosius, J. Kiem and J. Priesener, (eds.), Treatise on Invertebrate Paleontology, Part R, Arthropoda 4. Boulder, Colorado: Geological Society of America; and Lawrence, Kansas: University of Kansas Press. 665 p. 
Chippindale, P.T. et al., (1999). Phylogenetic Relationships of North American Damselflies of the Genus Ischnura (Odonata: Zygoptera: Coenagrionidae). Based on Sequences of Three Mitochondrial Genes. Molecular Phylogenetics and Evolution 11(1), 110-121.

Corbet, P. S. (1999). Dragonflies: Behavior and ecology of Odonata. Cornell University Press. Ithaca, New York.

Cooper, G., Miller, P. L., and Holland, P. W. H. 1996. Moleculargenetic analysis of sperm competition in the damselfly Ischnura elegans (Vander Linden). Proc. R. Soc. London B 263: 1343-1349.

Cordero, A. 1990a. The adaptive significance of the prolongued copulations of the damselfly, Ischnura graellsii (Odonata: Coenagrionidae). Anim. Behav. 40: 43-48.

Cordero, A. $1990 \mathrm{~b}$. The inheritance of female polymorphism in the damselfly Ischnura graellsii (Rambur) (Odonata:Coenagrionidae).Heredity 64: 341-346.

Cordero, A. 1992. Density-dependent mating success and colour polymorphism in females of the damselfly, Ischnura graellsii (Odonata: Coenagrionidae). J. Anim. Ecol. 61: 769_ 780 .

Cordero, A., and Miller, P. L. 1992. Sperm transfer, displacementand precedence in Ischnura graellsii (Odonata: Coenagrionidae). Behav. Ecol. Sociobiol. 30: 261-267.

Cordero Rivera, A.; M.O. Lorenzo Carballa; C. Utzeri \& V. Vieira. 2005. Parthenogenetic Ischnura hastata (Say), widespread in the Azores (Zygoptera: Coenagrionidae). Odonatologica, 34: 1-9.

Córdoba-Aguilar, A. (2008). Introduction. In: A. Córdoba-Aguilar (editor), Dragonflies and Damselflies: Study Models in Ecological and Evolutionary Research. Oxford University Press, Oxford, Pp. 1-3.

De Marmels J. (2001). Revision of Megapodagrion Selys, 1886 (Insecta, Odonata: Megapodagrionidae). (Diss. Doctor sci. nat.), Math.-naturwiss. Fak. Univ. Zurich. Zurich (Suiza). Pp. 218.

Dietz, R. S. \& Holden, J. C. (1970). Reconstruction of Pangaea: breakup and dispersion of continents, Permian to present. Jour. Geophys. Res., 75 (26), 4939-4956.

Dijkstra, K.-D.B. (2007). Demise and rise: the biogeography and taxonomy of the Odonata of tropical Africa. In: Dijkstra, K.-D.B. (Editor). Demise and rise: the biogeography and taxonomy of the Odonata of tropical Africa. PhD Thesis, Leiden University. 143-187.

Dijkstra, K.-D.B. (2007b). Gone with the wind: westward dispersal across the Indian Ocean and island speciation in Hemicordulia dragonflies (Odonata: Corduliidae). Zootaxa $1438,27-48$.

Feng, H.; K. Wu, Y. Ni, D. Cheng, \& Guo, Y. (2006). Nocturnal migration of dragonflies over the Bohai Sea in northern China. Ecol. Entomol. 31, 511-520.

Fincke, O. M. 1987. Female monogamy in the damselfly Ischnura verticalis Say (Odonata: Coenagrionidae). Odonatologica 16: 129-143.

Fincke, O.M. 2004. Polymorphic signals from harassed females and the males that learn them support a novel frequency-dependent model. Animal Behavior 67:833-845

Fraser, F. C. (1943). A note on the 1941 immigration of Sympetrum fonscolombii (Selys). (Odon.). J. Soc. Br. Entomol., 2, 133-136.

Fraser, F. C. (1945). Migration of Odonata. Entomol. Monthly Mag., 81,73-74.

Freeland, J. R., M. May, R. Lodge, \& Conrad, K. F. (2003). Genetic diversity and widespread haplotypes in a migratory dragonfly, the common green darner Anax junius. Ecological Entomology, 28, 413-421. 
Garrison, R. W. (1990) A synopsis of the genus Hetaerina with descriptions of four new species (Odonata: Calopterygidae). Transactions of the American Entomological Society, 116(l): 175-259

Grimaldi, D. \& Engel, M.S. (2005). Evolution of the Insects. Cambridge University Press.

Heiser, M. \& Schmitt, T. (2010). Do different dispersal capacities influence the biogeography of the western Palearctic dragonflies (Odonata)? Biological Journal of the Linnean Society, 99, 177-195.

Jarzembowski, E.A. \& Nel, A. (1996). New fossil dragonflies from the Lower Cretaceous of SE England and the phylogeny of the superfamily Libelluloidea (Insecta: Odonata). Cretaceous Research 17, 67-85.

Johnson, C. 1964. The inheritance of female dimorphism in in the damselfly Ischnura damula. Genetics 49: 513-519.

Johnson, C. 1966. Genetics of female dimorphism in Ischnura demorsa. Heredity 21: 453-459.

Johnson, C. 1975. Polymorphism and natural selection in ischnuran damselflies. Evol. Theory 1: 81-90.

Kormondy, E. J. (1961). Territoriality and dispersal in dragonflies (Odonata). J. N.Y. Entomol. Soc., 69, 42-52.

Lieftinck, M. A. (1962). Insects of Micronesia, Odonata. Insects Micronesia 5, 1-95.

Lieftinck, M.A. (1977). New and little known Corduliidae (Odonata: Anisoptera). from the Indo-Pacific region. Oriental Insects, 11(2), 157-159.

May, M. L., \& Matthews, J. H. (2008). Migration in Odonata: a case study of Anax junius, pp. 63-77. In A. Cordoba-Aguilar, (ed.), Dragonflies and Damselflies. Model Organisms for Ecological and Evolutionary Research. Oxford University Press, Oxford.

Matthews, J.H., S. Boles, C. Parmesan \& Juenger, T. (2007). Isolation and characterization of nuclear microsatellite loci for the common green darner dragonfly Anax junius (Odonata: Aeshnidae). to constrain patterns of phenotypic and spatial diversity. Molecular Ecology Notes.

McLachlan, R. 1896. Oceanic migration of a nearly cosmopolitan dragonfly (Pantala flavescens, F.). Entomol Mon. Mag. 7, 254.

Nelson, G., \& Platnick, N. I. (1981). Systematics and Biogeography: Cladistics and Vicariance. Columbia University Press, New York, 567 p.

Norberg, R. A. (1972). The pterostigma of insect wings as an inertial regulator of wing pitch. J. Comp. Physiol. 81, 9-22.

O'Grady, E.W. \& May, M.L. (2003). A phylogenetic reassessment of the subfamilies of Coenagrionidae(Odonata: Zygoptera). Journal of Natural History 37, 2807-2834.

Peck, S. B. (1992). The dragonflies and damselflies of the Galapagos Islands, Ecuador (Insecta: Odonata). Psyche (Camb.). 99, 309-322.

Petrulevičius, J. F. \& Nel, A. (2009). First Cordulephyidae dragonfly in America: A new genus and species from the Paleogene of Argentina (Insecta: Odonata). Comptes Rendus Palevol, 8 (4), 385-388.

Pilgrim, E. (2007).Systematics of the sympetrien dragonflies with emphasis on the phylogeny, taxonomy, and historical biogeography of the genus Sympetrum (Odonata: Libellulidae). Utah State University, 154 pp.

Pritchard, G., McKee, M. H., Pike, E. M., Scrimgeour, G. J. \& Zloty, J. (1993). Did the first insects live in water or air? Biol. J. Linn. Soc. 49, 31-44. 
Raven, P.H., \& Axelrod, D.I. (1974). Angiosperm biogeography and past continental movements. Ann. Mo. Bot. Gard. 61, 539-673.

Realpe, E. (2010). Two new Andean species of the genus Ischnura Charpentier from Colombia, with a key to the regional species (Zygoptera: Coenagrionidae). Odonatologica 39(2), 121-131.

Reichholf, J. (1973). A migration of Pantala flavescens (Fabricius, 1798). along the shore of Santa Catarina, Brazil (Anisoptera: Libellulidae). Odonatologica (Utr.). 2, 121-124.

Rosen, D. E. (1975). A vicariance model of Caribbean biogeography. Syst. Zool. 24, 431-464.

Rosen, D. E. (1978). Vicariant patterns and historical explanation in bio- geography. Systematic Zoology, 27, 159-188.

Rowe, R. J. (1987). The dragonflies of New Zealand. Auckland University Press, Auckland, New Zealand.

Russell, R. W.; M. L. May, K. L. Soltesz, \& Fitzpatrick, J. W. (1998). Massive swarm migrations of dragonflies (Odonata) in eastern North America. Am. Midl. Nat. $140,325-342$.

Samways, M.J. (1992). Dragonfly conservation in South Africa: a biogeographical perspective. Odonatologica, 21, 165-180.

Samways, M. J., \& Osborn, R. (1998). Divergence in a transoceanic circumtropical dragonfly on a remote island. J. Biogeogr., 25, 935-946.

Samways, M.J. (2006). National Red List of South African dragonflies (Odonata). Odonatologica 35, 341-368.

de Selys Longchamps, E. de, (1889). Palaeophlebia. Nouvelle leagion de Calopterygides. Suivi de la description d'une nouvelle gomphine du Japon: Tachopteryx pryeri. Annales de la Societeal Entomologique de Belgique 33, 153-159.

Stevens, L. E. \& Bailowitz, R. A. 2009. Odonata Biogeography in the Grand Canyon Ecoregion, Southwestern USA. Annals of the Entomological Society of America 102 (2), 261-274.

Srygley, R. B. (2003). Wind drift compensation in migrating dragonflies Pantala (Odonata: Libellulidae). J. Insect Behav. 16, 217-232.

Thomas, J.A., Trueman, J.W.H., Rambaut A. \& Welch, J.J. (in press). Relaxed Phylogenetics and the Palaeoptera Problem: Resolving Deep Ancestral Splits in the Insect Phylogeny.

Turgeon,J., Stoks,R., \& Thum, R.A., et al. (2005). Simultaneous Quaternary Radiations of Three Damselfly Clades across the Holarctic. The American Naturalist 165(4), 78-107.

van der Hammen, T and A. M. Cleef (1983) Trigonobalanus and the Tropical Amphi-Pacific Element in the North Andean Forest. Journal of Biogeography. 10(5), 437-440.

van Steenis, C.G.G.J., 1962. The land-bridge theory in botany, with particular reference to tropical plants. - Blumea 11: 235-542.

van Tol, J., Reijnen, B. T. \& Thomassen, H. A. (2009). Phylogeny and biogeography of the Platystictidae (Odonata). pp. 3-70 In: van Tol, J. Phylogeny and biogeography of the Platystictidae (Odonata). PhD. thesis, University of Leiden. $x+294 p p$.

Wakana, I. 1959. On the swarm and migratory flight of Pantala flavescens, an observation in Kawagoe area. Tombo 1, 26 -30 [in Japanese with English summary].

Ware, J.L., May, M.L., \& Kjer, K.M. (2007). Phylogeny of the higher Libelluloidea (Anisoptera: Odonata): An exploration of the most speciose superfamily of dragonflies, Molecular Phylogenetics and Evolution, 45, 289-310. 
Ware, J. L.; Simaika, J. P., Samways, \& M. (2009). Biogeography and divergence estimation of the relic Cape dragonfly genus Syncordulia: global significance and implications for conservation. Zootaxa, 2216, 22-36

Wiley, E. O. (1981). Phylogenetics: the theory and practice of phylogenetic systematics. John Wiley and Sons, New York.

Wikelski,M.,D., Moskowitz, J.S., Adelman, J., Cochran, D.S. Wilcove \& May, M. L. (2006). Simple rules guide dragonfly migration. Biology Letters, 1-5.

Wootton, R.J. (1981). Palaeozoic insects. Annual Review of Entomology, 26,319-344.

Watson, J. A. L. (1983). A truly terrestrial dragonfly larva from Australia (Odonata: Corduliidae). Journal of the Australian Entomological Society, 21, 309-11. 


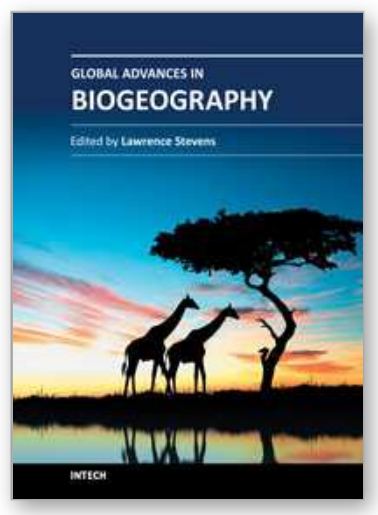

\author{
Global Advances in Biogeography \\ Edited by Dr. Lawrence Stevens
}

ISBN 978-953-51-0454-4

Hard cover, 360 pages

Publisher InTech

Published online 30, March, 2012

Published in print edition March, 2012

Global Advances in Biogeography brings together the work of more than 30 scientific authorities on biogeography from around the world. The book focuses on spatial and temporal variation of biological assemblages in relation to landscape complexity and environmental change. Global Advances embraces four themes: biogeographic theory and tests of concepts, the regional biogeography of individual taxa, the biogeography of complex landscapes, and the deep-time evolutionary biogeography of macrotaxa. In addition, the book provides a trove of new information about unusual landscapes, the natural history of a wide array of poorly known plant and animal species, and global conservation issues. This book is well illustrated with numerous maps, graphics, and photographs, and contains much new basic biogeographical information that is not available elsewhere. It will serve as an invaluable reference for professionals and members of the public interested in global biogeography, evolution, taxonomy, and conservation.

\title{
How to reference
}

In order to correctly reference this scholarly work, feel free to copy and paste the following:

Melissa Sánchez-Herrera and Jessica L. Ware (2012). Biogeography of Dragonflies and Damselflies: Highly Mobile Predators, Global Advances in Biogeography, Dr. Lawrence Stevens (Ed.), ISBN: 978-953-51-0454-4, InTech, Available from: http://www.intechopen.com/books/global-advances-in-biogeography/biogeography-ofdragonflies-and-damselflies-the-highly-mobile-predators-

\section{INTECH}

open science | open minds

\author{
InTech Europe \\ University Campus STeP Ri \\ Slavka Krautzeka 83/A \\ 51000 Rijeka, Croatia \\ Phone: +385 (51) 770447 \\ Fax: +385 (51) 686166 \\ www.intechopen.com
}

\author{
InTech China \\ Unit 405, Office Block, Hotel Equatorial Shanghai \\ No.65, Yan An Road (West), Shanghai, 200040, China \\ 中国上海市延安西路65号上海国际贵都大饭店办公楼405单元 \\ Phone: +86-21-62489820 \\ Fax: $+86-21-62489821$
}


(C) 2012 The Author(s). Licensee IntechOpen. This is an open access article distributed under the terms of the Creative Commons Attribution 3.0 License, which permits unrestricted use, distribution, and reproduction in any medium, provided the original work is properly cited. 